\title{
Global Challenges for the 21st Century: the Role and Strategy of the Agri-Food Sector
}

\author{
R. Webb ${ }^{1,3}$, J. Buratini' \\ ${ }^{1}$ Division of Animal Sciences, School of Biosciences, University of Nottingham, Nottinghamshire, UK. \\ ${ }^{2}$ Department of Physiology, Institute of Biosciences, São Paulo State University, Botucatu, SP, Brazil.
}

\begin{abstract}
Human activity is having an increasing global impact on the environment, geology and ecosystems. There is an $80 \%$ probability that world population will increase to between 9.6 billion and 12.3 billion by 2100 and could even reach 10 billion by 2056, 6 years earlier than projected. Historically, global production of food has outpaced consumption growth. This is evidenced by falling real prices of food, however this is now slowing, caused by constraints on supply and continued growth of demand. Paradoxically, as billions suffer food insecurity through lack of food, more than 2 billion people, approximately $30 \%$ of the world's population, are overweight or obese and this percentage continues to grow. It is also estimated that the world will need to close a significant food-gap by 2050 , primarily because of continued population growth and changing diets. Increases in temperature of over two degrees Celsius are projected to have a negative impact on global yields of major crops. Agri-food production, including manufacture, food preparation and cooking, accounts for approximately $30 \%$ of all greenhouse-gas emissions and livestock production accounts for approximately $50 \%$ of this. The agricultural sector will increasingly be driven by these global changes, including a rising world population, rapid development of emerging economies, with western lifestyle aspirations, growing geopolitical instability around shortages of land, water and energy and 'one health' issues. However, a technological revolution is taking place, including breakthroughs in nutrition, genetics, informatics, satellite imaging, remote sensing, meteorology, precision farming and low impact agriculture. These changes will hopefully continue to drive major global investment in agricultural technologies. It is of vital importance that countries around the world recognize fully the opportunities and challenges and provide the appropriate framework support, investment and infrastructure. In this regard, increasing high quality livestock research will be essential to help address the looming food and environmental challenges and is a message that animal scientists and veterinarians around the world need to be making to governments and funding agencies. Farming practices globally will continue to change because of competing demands. Hence it is essential that the livestock sector benefits fully, both from continued improvements of current reproductive technologies and in the application of future reproductive technologies to meet these global challenges.
\end{abstract}

Keywords: food security, greenhouse gases, livestock, sustainability, technology.

\section{Introduction}

It has been proposed that the world is entering, or may have even entered, the anthropocene epoch from the holocene epoch, because human activity is having a significant global impact on the Earth's environment, geology and ecosystems (Zalasiewicz et al., 2015). In a recent EU report (Expo Milano, 2015, EU Scientific Steering Committee Recommendations) there was a summary of some of the key global issues. For example, it stated that nearly 1 billion people are chronically hungry. In comparison, because of over consumption of food, coupled with reduced physical activity, approximately twice as many people are overweight. Furthermore in Paris in December 2015, 195 countries agreed to try and keep global temperature rise to well below the $2^{\circ} \mathrm{C}$ above pre-industrial levels, and to even pursue efforts towards $1.5^{\circ} \mathrm{C}$, since increases in temperature of over two degrees Celsius are expected to have a negative impact on global yields of major crops (Intergovernmental Panel on Climate Change (IPCC), 2012; 2013; Climate and Global Production Shocks Report, 2015). Unfortunately however, the agricultural sector was largely absent from the talks in Paris (Benton and Bajželj, 2016). Hence the impact of enhanced human endeavor and activity, coupled with continued population growth, will result in increasing global challenges throughout the $21^{\text {st }}$ century. This paper outlines a number of the global challenges, the impact of livestock production and possible mitigation strategies, including the development and benefit of new technologies. These are discussed together with possible strategies that countries, individually and in collaboration, could develop to meet the challenges, using examples of current programs in the UK and Brazil.

\section{The Global Challenges}

The focus of this review is on population growth, food security, climate change and livestock production. However the additional impact of other challenges, such as the links between animal and human health, zoonotic diseases, and the increase in antibiotic resistance, need to be recognized.

\section{Population growth}

World population at time of writing currently stands at around 7.5 billion, with a population growth of

${ }^{3}$ Corresponding author: bob.webb@nottingham.ac.uk 
approximately 200,000 per day. At the dawn of agriculture, at approximately 8,000 B.C., the world population was estimated to be 5 million, with a growth rate of less than $0.05 \%$ to reach about 2 to 300 million by 1 A.D. A significant change occurred with the industrial revolution at approximately 1,800 A.D. with the second billion being achieved in only 130 years. Peak annual growth rate occurred in the 1960s when it was approximately $2.2 \%$, but it is currently declining and is around $1.15 \%$ per year. The United Nations recently released population projections based on data until 2012. Analysis of these data reveals that, contrary to previous projections, and despite the decline in birth rate, the world population is unlikely to stop growing this century. Indeed there is an $80 \%$ probability that world population will increase to between 9.6 billion and 12.3 billion by 2100 and could even reach 10 billion by 2056, 6 years earlier than projected. Much of the increase is expected to happen in Africa, in part because of increased rates of fertility and a recent slowdown in the pace of fertility decline. Also, the ratio of workingage people to older people is likely to decline substantially in all countries, even those that currently have young populations (Gerland et al., 2014). Current mean world figures from the World Bank indicate that the proportion of people over the age of 65 is currently greater than $8 \%$, but this increases towards $20 \%$ for some countries in Western Europe.

Recent figures from the United Nations Department of Economic and Social Affairs, Population Division show more women than ever now use family planning, with some poorer regions recording the fastest pace of growth since 2000 . In 2015 an estimated $64 \%$ of either married women or women living with a partner aged between 15 to 49 years used family planning, compared with $36 \%$ in 1970 . However, despite the success of the past 40 years it has been concluded that investment in family planning is needed to keep up with demand and meet the need of women who are unable to access services (see Population Council). Furthermore in a recent comment in the Lancet (World Abortions 1990 to 2014, 2016) it was concluded that additional knowledge, regarding the incidence of induced abortion, is needed to motivate and inform efforts to help women avoid unintended pregnancies and to monitor progress toward that end. It was estimated that abortion rates have declined significantly since 1990 in the developed world, but not in the developing world. An important conclusion was that ensuring access to sexual and reproductive health care could help millions of women avoid unintended pregnancies and ensure access to safe abortion.

In summary, despite the success in contraceptive use, world population continues to grow, resulting in increased demand for food and resources. The Food and Agriculture Organisation (FAO) food demand projections and World Resources Institute (WRI; Ranganathan et al., 2016), estimate that the world will need to close at least a 60 percent "food gap" between the crop calories available in 2006 and expected caloric demand in 2050 (Foley, 2011). In conclusion, the food gap will stem primarily from continued population growth and changing diets.

\section{Food security}

Food security, as defined by the FAO, occurs when: all people, all of the time, have physical, social and economic access to sufficient, safe and nutritious food that meets their dietary needs and food preferences for an active and healthy life. Despite progress there are currently over 800 million people who are chronically hungry in the developing world, with more than 3 million children dying each year from the causes of under- and mal-nutrition and an estimated 160 million under 5-year-old children who are stunted and will carry the burden of this through their lives. Globally we are far from being food secure (World Hunger and Poverty Facts and Statistics, 2015). Indeed it is estimated that around 2 billion more people suffer from either iron deficiency (World Health Organization - WHO, 2012) or other micronutrient deficiencies caused primarily by the lack of access to food and this is in most cases due to relative or absolute poverty. For example, limited access to food and rapid food price inflation can be a cause of civil unrest and drive human migration. Paradoxically, as billions suffer food insecurity through lack of food, more than 2 billion people, approximately $30 \%$ of the world's population, are overweight or obese and this percentage continues to grow (WHO, 2015). This is often associated with poverty and is a consequence of over-consumption of calories, the lack of access to appropriate nutrition, as well as a lack of physical activity. Furthermore, caloric overconsumption progressively increases personal, publichealth and environmental costs and thereby increases the pressure not only on the global food supply, but also on national health systems. In summary, food and nutrition security is an issue for all societies. Importantly however, the FAO estimates that there is enough food in the world to provide every single person each day with approximately 2,770 kcal (FAO, 2012; World Hunger and Poverty Facts and Statistics, 2015).

Historically, global production of food has outpaced consumption growth as evidenced by falling real prices of food. However, this "outpacing" is now slowing because of constraints on supply, alongside continued growth of demand (European Commission, 2011). For example, more people are demanding more food that is more resource-intensive to produce such as meat. In addition, in most places there is considerable food wastage. On the supply-side, historic yield growth has slowed or even plateaued in recent years and this has been the case for the UK. The acceptability of technological solutions to increasing yields is sometimes resisted, as has occurred in the EU (European Commission, 2011). In addition, there is increased competition for land, water and other natural resources, which may impact on global food production and climate change and is also threatening production growth in many areas. A further constraint is that reducing the environmental impact of agriculture, aquaculture and fisheries, including greenhouse gas emissions, while maintaining production will probably 
require changes in the way food is produced.

How can changing diets, including the type, combination, and quantity of foods people consume, contribute to a sustainable food future? As discussed, global population is projected to grow to nearly 10 billion people by 2050 , with two-thirds of those people projected to live in cities. In addition, at least 3 billion people are expected to join the global middle class by 2030. As nations urbanize and citizens become wealthier diets change, with people generally increasing both their calorie intake and the share of resourceintensive foods, such as meat and dairy, in their diets. Over the last 40 years, the worldwide consumption per capita of milk has doubled, and meat consumption has more than tripled (Kearney, 2010).

At the same time globalization, technological advances, business and economic changes, and government policies are transforming entire food chains. Multinational businesses are increasingly influencing what is grown and what people eat. Together, these are driving trends toward Western-style diets, which are high in calories, protein and animalbased foods. Indeed in China meat consumption has increased nine fold (Kearney, 2010). Although some of this shift reflects health and welfare gains for many people, including increased longevity, the scale of this ongoing change in diet will make it harder for the world to achieve a number of the United Nations sustainable development goals, which include reducing hunger, improving healthier lives, improved water management, combating climate change, and protecting terrestrial ecosystems (Ranganathan et al., 2016). In summary given recent trends, demand is likely to rise more quickly than supply towards the middle of the $21 \mathrm{st}$ century increasing the pressure to convert more land for farming. The combination of these drivers suggests that emissions from the agri-food sector will continue to grow. Changing some farming practices could offset some of this increase, but achieving such changes will be a challenge and require continued collaborative research and development across continents.

\section{Climate change}

The negative impact of climate change, including an increase in temperature of over two degrees Celsius (Intergovernmental Panel on Climate Change - IPCC, 2012, 2013; Climate and Global Production Shocks Report, 2015), on global yields of major crops will probably be spread unevenly over the globe. It is projected that crop production in low latitudes will experience negative effects, whereas in northern latitudes impacts may vary. The areas where climate change is expected to threaten crop productivity the most (Wheeler and von Braun, 2013) include countries in Africa and South Asia, that are home to many of the world's more than 800 million undernourished people (FAO, 2014). Food production of the globally most important commodity crops, maize, soybean, wheat and rice, comes from a relatively small number of major producing countries. The exposure of a large proportion of global production of the major crops is therefore concentrated in specific parts of the globe. This report stresses that extreme weather events, in these regions, will have the largest impact on global food production. Furthermore, simultaneous extreme weather events in two or more of these regions, creating a 'multiple bread basket' failure, would represent a serious production shock. However, understanding the underlying cause of extreme weather events in different production regions is currently under-researched.

There is an urgent need to understand the dynamics of meteorological events, such as the El Niño, which may become even more extreme, in order to quantify the likelihood of production shocks in major food-producing regions. Indeed it is projected that a catastrophe is developing currently in Africa because of crop failure caused by the impact of El Niño. It has been estimated that 50 million people, across a number of countries, could require food-aid during the next 12 months. Initial modeling by a US-UK Taskforce (Extreme Weather and Resilience of the Global Food System Report, 2015) suggests that what would be called an extreme food production shock in the late $20^{\text {th }}$ century, will become more common in the future. The data suggest that a 1 in 200 year event for the climate in the late $20^{\text {th }}$ century equates to a loss of approximately $8.5 \%$ production, and over the next decades (2011 to 2040), a 1 in 200 year event is about $15 \%$ larger in magnitude and equivalent to the loss of $9.8 \%$ of calorie production. Furthermore, according to the model an event that would have been called 1 in 100 years over the period from 1951 to 2010 may become as frequent as a 1 in 30 year event before the middle of the current century.

Agriculture and the production of food is a very significant emitter of greenhouse gases, causing emissions of $\mathrm{CO}_{2}$ by agricultural machinery and the transportation of crops and animals, nitrous oxide from the use of fertilizers (synthetic and manure), and methane from livestock and flooded paddy fields for rice (Smith et al., 2014). Furthermore, the demand for food has led to a global expansion of farmland at a rate of about 10 million hectares per year during the last decade. Some of this cleared land was tropical rainforest, adding more emissions and reducing the capacity of land to absorb and store carbon. There have been a number of estimates of greenhouse gas emissions from agriculture and food production that vary depending on methodology. For example, the estimate of $30 \%$ by Bajželj et al. (2013) includes the manufacture, preparation and the cooking of food. A more recent study calculated that agriculture, forestry and other parts of the land use sector is responsible for just under a quarter (approximately 10 to $12 \mathrm{GtCO}_{2}$ eq

per year) of anthropogenic greenhouse gas emissions, mainly from deforestation and agricultural emissions from livestock, soil and nutrient management (Smith et al., 2014). Furthermore, according to the Food and Agriculture Organization of the United Nations (FAO, 2014), agri-food production and forestry was estimated to account for approximately $20 \%$ of all greenhouse-gas emissions in the world $(25 \%$ in America, $12 \%$ in Europe, $15 \%$ in Africa, $4 \%$ in Oceania and $44 \%$ in 
Asia). Overall however, producing and cooking the food we eat results in approximately the same amount of emissions as those produced from personal travel, lighting, heating and air conditioning and domestic 'white goods' combined.

\section{Livestock production}

The livestock sector supports about 1.3 billion producers and retailers worldwide, and contributes 40 to $50 \%$ of agricultural gross domestic product (Herrero et al. 2016). These authors estimated that between 1995 and 2005, the livestock sector was responsible for greenhouse gas emissions of 5.6 to $7.5 \mathrm{GtCO}_{2} \mathrm{e}$ per year which comprises approximately $50 \%$ of agricultural emissions. However, livestock accounts for up to half of the technical mitigation potential of the agriculture, forestry and land-use sectors. This will be through the application of management options that sustainably intensify livestock production, promote carbon sequestration in rangelands, reduce emissions from manures, and through reduction in the demand for livestock products. Although the mitigation potential of reductions in livestock product consumption is large, their economic potential is unknown at present (Herrero et al., 2016).

Livestock, particularly ruminants, can eat a wider range of biomass than humans, although in the drive for greater efficiency, intensive systems of livestock production have evolved to compete with humans for high-energy crops such as cereals. In a study by Wilkinson (2011), feeds consumed by livestock were analyzed in terms of the quantities used and efficiency of conversion of grassland, human-edible crops and crop by-products into milk, meat and eggs, using the United Kingdom as an example of a developed livestock industry. It was concluded that by accounting for the proportions of human-edible and inedible feeds used in typical livestock production systems, a more realistic estimate of efficiency could be made by comparing systems. Therefore increasing efficiency in livestock production and reducing the share of animal products in human consumption are two possible strategies to curb the adverse environmental impacts of the livestock sector. In a recent study, Schrader et al. (2016) explored the opportunity for sustainable livestock production by modeling the impacts and constraints of a third strategy in which livestock feed components, that compete directly with human food crop production, are reduced. Thus animals are fed only from grassland and byproducts from food production. They show that a strategy focusing on feed components, which do not compete directly with human food consumption, offers a viable complement to strategies focusing on increased efficiency in production and/or reducing the share of animal products in human consumption (Schrader et al., 2016).

In conclusion, one of the key challenges in the livestock sector will be the development of technological advances in sustainable intensification. However, this approach will be only one mitigation route together with decreases in food waste and improvements in human diets (Bajželj et al., 2014).

\section{Agri-Food Technology Strategy}

Agricultural science and technology is one of the world's fastest growing and exciting sectors within the global marketplace. As discussed, this market will be driven by global changes including a rising world population, rapid development of emerging economies with western lifestyle aspirations and growing geopolitical instability around shortages of land, water and energy. In parallel a technological revolution is also taking place, including breakthroughs in nutrition, genetics, informatics, satellite imaging, remote sensing, meteorology, precision farming and low impact agriculture. These changes will continue to drive major global investment in agricultural technologies. It is of vital importance that countries around the world recognize fully the opportunities and challenges and provide the appropriate framework support and investment.

Recognizing these challenges, including the continuing reduction in food self-sufficiency in the United Kingdom, the UK Government launched 'A UK Strategy for Agricultural Technologies' (UK Government, 2013). In 2016 the strategy was expanded to incorporate the food production and retail sector, as well as primary agricultural production, and is overseen by the AgriFood Technology Council. This strategy is aimed at improving the integration of UK's science and progressive food and farming businesses with the Government's support for trade, investment and international development. The aim is to help unlock a new phase of global leadership in agricultural innovation. The vision of the strategy is that the UK becomes a world leader in agricultural technology, innovation and sustainability; exploits opportunities to develop and adopt new and existing technologies, products and services to increase productivity; and thereby contributes to global food security and international development.

The mission of the strategy includes (1) additional investment from both government and industry in agricultural research and innovation, including the launch of four new research innovation centers (Agrimetrics, Crop Health and Protection, Livestock, Agricultural Engineering Precision) and investment in a significant number of applied research projects, supporting the speedier translation of research into practice i.e. from farm to fork through agri-food supply chains; (2) promoting the UK's expertise and capacity in the agri-tech sector to stimulate investment, creating a new generation of spin-outs and start-up ventures, increasing export opportunities and new collaborations with emerging and developing economies; (3) take a global lead in agricultural informatics and in establishing the metrics and techniques by which progress towards sustainable intensification can be assessed; (4) encourage investment in change, including enhanced skills and knowledge transfer, exploitation of shared data and widespread adoption of best practice. In addition, the 
UK Government has just announced a $£ 1.5$ billion Global Challenges Research Fund, across the Research Councils, to support cutting-edge research that addresses the challenges faced by developing countries. There has also been a significant focus on skills given that it will be essential to have an increasingly skilled workforce to take full advantages of the rapid pace of technological progress, not only within the agricultural sector, but also across other sectors such as informatics and engineering.

Brazil has also promoted programs to mitigate the environmental threats associated with the global challenges, as discussed, and to reduce food shortage within its boundaries. The Brazilian Agricultural Research Corporation (Embrapa) - Ministry of Agriculture, Livestock and Food Supply launched a number of programs aiming to reduce poverty and hunger and also to stimulate agricultural technologies supporting environmentally safe food production. The "Brazil Without Extreme Poverty" program, which aims to increase familiar agricultural production and to enhance/create markets for these products, and the "Low Carbon Agriculture Plan" (ABC Plan) are perhaps the most relevant and emblematic actions from the Brazilian government within the context of the global challenges. A relevant program, with the ABC Plan directly linked to livestock production, is the National Integrated Crop-Livestock-Forestry (ICLF) Policy, which targets the rehabilitation of degraded pastures and forests by the development of integrated systems.

In conclusion, it is essential that the livestock sector can take full benefit of the funding initiatives that are being launched worldwide and continue to develop new reproductive technologies to be better placed to respond to the global challenges.

\section{Reproductive Technologies in the $21^{\text {st }}$ Century}

In 2012 Murphy made a presentation to the Sociedade Brasileira de Transferência de Embriões (SBTE) on 'The future of animal reproduction'. The accompanying review paper discussed a range of current technologies, including artificial insemination, including classical genetic selection approaches (Murphy, 2012). The review paper also stressed the major limitations to the use of these technologies in extensive production systems, together with the use of additional technologies including prostaglandins to regress corpora lutea, progestagens to mimic luteal function, regulation of follicular development with estrogens or GnRH, and synchronization of ovulation with either GnRH and/or estrogens (Bó et al., 2007; Lamb et al., 2010; Baruselli et al., 2011). Although these technologies have a number of benefits, there still remains substantial potential for improvement in the rate of successful pregnancy, despite these compounds being available for nearly 50 years.

Other current technologies include the use of sexed semen and embryo transfer which has become more widespread, particularly in South America who leads the world (over 70\%) in the number of in vitro produced embryos (Blondin, 2015). However, the success of this technology is still limited by the efficacy of the superovulation protocols, including the variability of the follicular reserve (Mapletoft and Bó, 2011; Ireland et al., 2011) and the variation between Bos taurus and Bos indicus breeds (Morotti et al., 2015; Sartori et al., 2016a), and in vitro embryogenesis protocols (Baruselli et al., 2015). The review paper of Sartori et al. (2016b), published in these proceedings, describes the development and magnitude of the reproductive technologies in use in Brazil, and also discusses the technical bottlenecks that limit the impact on animal production efficiency. Among the current limitations, special focus has been given to sub-optimal protocols for oocyte maturation and embryo culture leading to low blastocyst development rates (averaging 25 to $50 \%$ ), which compromise conception rates and successful pregnancy outcome. In addition, embryonic developmental competence is compromised further by inefficient freezing protocols. Once these bottlenecks are minimized, the impact of in vitro embryo production on livestock productivity is expected to increase significantly, particularly when used in combination with the development of DNA based strategies for donor selection as indicated below.

Continuing, and indeed even an increase, in livestock research and development will be essential to help address the looming food and environmental challenges and is a message that animal scientists around the world need to be making to their governments and funding agencies. However, the message should also be one of optimism, given the untapped potential of our farm species. The potential yields of plant and animal farm species, including constraints and opportunities in the 21 st century, has been reviewed and considered extensively (SylvesterBradley and Wiseman, 2005). For livestock the opportunities include (i) increasing the proportion of twin births in cattle, (ii) more precise control of seasonality, litter size, lamb survival and puberty in sheep, (iii) increased fecundity in pigs, (iv) increased milk yield in dairy cows and sheep, (v) improving feed conversion efficiency, meat quality and growth in sheep and beef cattle. However, to obtain these benefits improved animal management, welfare and feeding strategies will be required (Sinclair and Webb, 2005; Webb et al., 2005; Garnsworthy and Thomas 2005). In all species the predicted trends for increased yields, accompanied by increases in efficiency, are projected to reduce environmental impact of animal agriculture, mainly through reductions in animal numbers required for a given output of meat and dairy (Garnsworthy, 2004). However it is important to realize that a more systems based approach to production will be required, together with the incorporation of new physiological and genetic technologies. Furthermore, despite large genetic improvements in the quantitative traits of growth, production, and efficiency of farmed livestock over recent decades, current evidence suggests that little variation has been lost and that improvements should indeed be sustainable in the future (Hill, 2016).

Traditional marker-assisted selection did not result in the widespread use of DNA information in 
animal breeding (Meuwissen et al., 2016). The main reason was that the traits of interest in livestock production are much more complex than expected and are determined by thousands of genes with small effects on phenotype (Haley et al., 1993). However, advances in genotyping and sequencing a little over a decade ago have resulted in the development and application of genomic selection, which is arguably the most important breakthrough in animal breeding since the development of best linear unbiased prediction in the 1940s (see Hickey et al., 2016).

Genomic selection assumes that all markers might be linked to a gene affecting the trait and concentrates on estimating their effect, rather than testing its significance. Three technological breakthroughs resulted in the current widespread use of DNA information in animal breeding: (i) the development of genomic selection technology, (ii) the discovery of massive numbers of genetic markers (single nucleotide polymorphisms, SNPs), and (iii) high-throughput technology to genotype animals for hundreds or even thousands of SNPs in a cost-effective manner. The use of whole genome sequence data is anticipated to have a significant impact on dairy and beef cattle, pigs, and poultry breeding (Meuwissen et al., 2016). For example in sheep and goat breeding, rapidly reducing genotyping cost, coupled with a better understanding of how to maximize benefits of genomic selection should result in a dramatic rise in the adoption of these approaches (Rupp et al., 2016). In beef cattle the development of accurate genomic evaluations in beef populations are more difficult than in dairy populations because of the presence of multiple breeds, the poor extent of phenotyping, lack of the use of artificial insemination (Berry et al., 2016), and sheep and beef systems are generally lower-margin businesses and hence tend to be slower adopters of technology. However, the ongoing development of low cost sensors, such as ultra-wide band technology for estrous detection (Homer et al., 2013), and associated information technology for the generation and capture of phenotypes should have a positive impact. These types of technologies, coupled with international initiatives, suggest that the necessary framework is in place for further development of genomic predictions certainly for beef, and possibly even for sheep (Berry et al., 2016).

In addition and significantly, genome editing in livestock populations of cattle, sheep and pigs, has resulted already in viable zygotes and living animals. The idea of genome editing appears straight forward, in that base pairs at specific locations in the genome can be deleted, changed or added (Hickey et al. 2016). Importantly, these changes are permanent and if made in germ line cells, are heritable and advances in this technology are occurring regularly. From an animal breeding perspective, roles for genome editing include (i) fix favorable alleles for monogenic traits (e.g. disease resistance, myostatin, polledness), (ii) removal of recessive alleles that impact on fertility and (iii) increase the frequency of favorable alleles for polygenic traits (Hickey et al., 2016). These advances, coupled with increased understanding of epigenetic effects (Sinclair et al., 2007), will bring understanding, but both opportunities and challenges, that can potentially be included in livestock breeding programs. These include the need for a relatively inexpensive technology to sequence the epigenome on a large scale, and in large numbers of individuals, to accurately estimate epigenetic variance at a population level. Statistical methods also need to be developed to incorporate whole methylome information together with large environment and DNA sequence information. Practical implementation must be carefully evaluated to successfully incorporate epigenetic information in livestock breeding, including mate selection, in order to obtain genotypes that favor a certain epigenotype (González-Recio et al., 2015). In summary, multidisciplinary genetic and management/nutrition practices could result in the incorporation of favourable epigenotypes into populations, in addition to technologies such as genome editing.

\section{Conclusions}

The food security, world population and climate change challenges are clear. Food security for the majority of the world's population is about nutrition for a healthy life, not calories to survive. Greater than $50 \%$ of the world's population are malnourished, either over- or under-weight, and the global economic burden of non-communicable diseases (Alleyne et al., 2013) is growing rapidly. Indeed it is viewed as one of the major challenges for sustainable development in the $21^{\text {st }}$ century. For example, in many countries, poverty and obesity are correlated, with inadequate diets in the urban poor being a significant issue, alongside other developing world micronutrient and calorie deficiencies.

As discussed, the IPCC challenge is to limit climate change to less than $2^{\circ} \mathrm{C}$, which will require more sustainable consumption. As the emissions from agri-food are approximately $30 \%$ of global emissions, and are continuing to grow not shrink, the argument that demand is increasing and so we must grow more to meet this demand is increasingly recognized as being unsustainable. This will result in a stronger focus on the demand-side measures, such as dietary change and waste reduction.

There has been much debate on dietary change and on livestock production. For example, there is ongoing discussion that humans should eat less meat, particularly as the average person, in more than $90 \%$ of the world's countries and territories, consumed more protein than the estimated daily requirement (Ranganathan et al., 2016). Alternatively humans should eat more grass fed beef and sheep, in addition to eating less meat, and/or eat more chicken versus eating less red meat. The recent WRI report indicates that there is no current "protein crisis" as on average every region of the world consumes more protein than is required, although it is expected that "demand driven desire" for protein consumption will grow. It is clear that a significantly more sustainable, or even a reduction, in ruminant meat and dairy consumption will be 
indispensable for reaching the $2{ }^{\circ} \mathrm{C}$ target, unless unprecedented advances in technology, such as the green revolution that occurred 50 years ago (Borlaug, 2000), are repeated (Hedenus et al., 2014).

There are three possible ways we could respond to this sobering conclusion: (i) we carry on as we are and miss the IPCC Paris targets, and therefore perhaps lock us into 4 to $5^{\circ} \mathrm{C}$ of global warming by the end of the century. (ii) We rely on research and innovation to find ways to significantly increase yields to reduce the rate of land conversion and develop carbon capture and storage. (iii) $\mathrm{We}$ recognize that demand for food is driving emissions and work to make changes meet the supply-side improvements halfway ( $\mathrm{T}$. Benton, 2016; University of Leeds).

The first option is not a viable long-term strategy. The second option has possibilities, but there is little evidence of research budgets on the necessary scale that will be required being forthcoming, indeed globally research budgets have been decreasing in some countries. Furthermore there is a significant gap between mitigation potential and economic viability Hence the third option seems, at least currently, the better way forward.

It is clear that our habits globally, with specific exceptions, have changed rapidly in recent decades. More food is consumed per capita, generally food is cheaper with respect to income, there is significantly more choice and availability, and importantly there is significant waste. However, there is no reason why habits could not change again to achieve a more sustainable lifestyle? A positive start would be to reduce food waste. For example, on a global basis, about a third of food is lost in either fields and/or storage, or wasted in the supply chain and in our homes. Wasting food is not just a waste of valuable resources it also causes additional emissions when ending up in landfill sites. For example, food waste costs the average UK family, with children, approximately US $\$ 1,000$ per year.

One option is to reduce consumption of intensively produced meat and dairy. Raising livestock is a less efficient way of producing food than growing crops. Currently, a third of the crops we grow are fed to livestock to produce meat, and nearly half of the emissions from agri-food are related to meat production, more than the entire transport sector. If we used the land that is currently growing feed for animals to grow mainly food for humans, and consume only milk and meat from pasture/byproduct-fed animals, there is scope for very significant reduction in emissions. If we continue to consume increasing amounts of non-pasture fed animals, then the choice of meat is important because producing beef emits more than five times as much as chicken and pork, although as discussed previously, a robust assessment of feed efficiency is required (Wilkinson et al., 2011) in the context of obtaining more realistic estimates of emissions.

Increasingly, people around the world eat more calories than are good for them and as stated previously, about two billion adults are either overweight or obese and this number continues to grow. In Europe, for example, the population consume around twice as much meat as is deemed healthy, whereas in the United States this number is three times. Hence a global switch towards more plant-based diets would reduce global mortality by up to $10 \%$ and food-related greenhouse gas emissions by as much as $70 \%$ by 2050 (Springman et $a l ., 2016)$. It means that adjusting diets and attitude to waste has the potential to make the Paris targets more achievable. In a very recent modeling study, Herrero et al. (2016) concluded that the mitigation potential of reductions in livestock product consumption is large, but their economic potential is unknown at present.

Finally, one further global challenge that will have increasing impact during the 21 st century, and has not been discussed in detail in this review, is the link between animal health and human health, zoonotic diseases, and the increase in antibiotic resistance (see Wegener, 2012). The epidemiology of antimicrobialresistant microorganisms at the human-animal interface is complex, although it is estimated that the volume of antimicrobials used in food animals exceeds their use in humans worldwide. The One Health agenda (Gibbs, 2014) is gaining significant traction worldwide when it comes to addressing zoonotic transmission of pathogens that are resistant to antimicrobials. There will be an increasing need to engage a wide range of stakeholders, not only researchers, but also farmers, veterinarians, food safety professionals, medical doctors, as well as environment and wildlife experts in monitoring and controlling activities and coordinating responses to this global challenge, that will definitely occur.

It is clear that more research and investment are needed to increase the affordability and uptake of mitigation practices, to moderate consumption of livestock products where appropriate, and to avoid negative impacts on livelihoods, economic activities and the environment. Importantly however, limited take-up of new farming methods, together with high costs, means that a relatively small proportion of what is technically possible is currently economically viable. Continued advances in the use of current reproductive technologies, together with the development of new reproductive technologies will be essential.

In conclusion, the future focus should be on the development of system-based approaches (Randolph et al., 2007), together with the cost effective and welfare friendly use of new technologies and farming practices. This strategy should ensure that the application of new technologies, that will certainly become available during the 21 st century, should assist in maximizing the efficiency and sustainability of livestock production and reduce environmental impact. In this regard, it is worth remembering the comment that "It is not the strongest of the species who survive, nor the most intelligent; rather it is those most responsive to change" (attributed to L. C. Megginson when interpreting Charles Darwin's Origin of Species, 1963).

\section{Acknowledgments}

Professor Tim Benton, UK Champion for Global Food Security and Professor of Population 
Ecology, University of Leeds, and Professor Geoff Simm, AgriFood Technical Council and SRUC, Edinburgh, for information and insightful discussion.

\section{References}

Alleyne G, Binagwaho A, Haines A, Jahan S, Nugent R, Rojhani A, Stuckler D. 2013. Non-communicable diseases 1. Embedding non-communicable diseases in the post-2015 development agenda. Lancet, 381:566-574.

Bajželj B, Allwood JM, Cullen JM. 2013. Designing climate change mitigation plans that add up. Environ $\mathrm{Sci}$ Technol, 47:8062-8069.

Bajželj B, Richards KS, Allwood JM, Smith P, Dennis JS, Curmi E, Gilligan CA. 2014. Importance of food-demand management for climate mitigation. Nat Clim Change, 4:924-929.

Baruselli PS, Ferreira RM, Sales JN, Gimenes LU, Sá Filho MF, Martins CM, Rodrigues CA, Bo GA 2011. Timed embryo transfer programs for management of donor and recipient cattle. Theriogenology, 76:15831593.

Baruselli PS, Vieira LM, Batista EOS, Ferreira RM, Sales JNS, Gimenes LU, Torres-Junior JRS, Martins CM, Sá Filho MF, Bó GA. 2016. Updates on embryo production strategies. Anim Reprod, 12:375-382.

Benton T, Bajželj B. 2016. Where was food in the COP21 Paris agreement. Available on: http://www.foodsecurity.ac.uk/ blog/2016/04/wherewas-food-in-the-cop21-paris-agreement.

Berry DP, Garcia JF, Garrick DJ. 2016. Development and implementation of genomic predictions in beef cattle. Anim Front, 6:32-38

Blondin P. 2015. Status of embryo production in the world. Anim Reprod, 12:356-358.

Bó GA, Cutaia L, Peres LC, Pincinato D, Marana D, Baruselli PS. 2007. Technologies for fixed-time artificial insemination and their influence on reproductive performance of Bos indicus cattle. Soc Reprod Fertil Suppl, 64:223-236.

Borlaug NE. 2000. Ending world hunger. The promise of biotechnology and the threat of antiscience zealotry. Plant Physiol, 124: 487-490.

Climate and Global Crop Production Shocks Report 2015. Resilience taskforce sub-report. Available on: www.foodsecurity.ac.uk/assets/pdfs/climate-and-globalcrop-production-shocks.pdf. 28 pp.

European Commission. Standing Committee on Agricultural Research. 2011. Sustainable food consumption and production in a resource-constrained world. $147 \mathrm{pp}$. Available on: https://ec.europa.eu/ research/agriculture/scar/pdf/scar_feg_ultimate_version. pdf.

European Commission. Joint Research Centre. 2015. New ways of providing knowledge to tackle food nutrition security. What should the EU do? Expo 2015: EU Scientific Steering. Committee: Recommendations. 64 pp. doi: $10.2788 / 877760$.

Extreme weather and resilience of the global food system. 2015. Final Project Report from the UK-US Taskforce on Extreme Weather and Global Food System Resilience, The Global Food Security Programme, UK.
Available on: www.foodsecurity.ac.uk/assets/pdfs/ extreme-weather-resilience-of-global-food-system.pdf.

Foley JA. 2011. Can we feed the world; sustain the planet? Sci Am, 305:60-65.

Food and Agriculture Organization. 2012. World agriculture towards 2030/2050: The 2012 Revision. ESA Working Paper No. 12-03, Rome. Available on: http://www.fao.org/fileadmin/templates/esa/Global_pers epctives/world ag 2030502012 rev.pdf.

Food and Agriculture Organization. 2014. Climate change. Available on: http://www.fao.org/resources/ infographics/infographics-details/en/c/218650.

Food and Agriculture Organization, International Fund for Agricultural Development, World Food Programme. 2014. The state of food insecurity in the world, 2014. Strengthening the enabling environment for food security and nutrition. Rome. Available on: http://www.fao.org/3/a-i4030e.pdf.

Garnsworthy PC. 2004. The environmental impact of fertility in dairy cows: a modelling approach to predict methane and ammonia emissions. Anim Feed Sci Technol, 112:211-223.

Garnsworthy PC, Thomas PC. 2005. Yield trends in UK dairy and beef cattle. In: Sylvester-Bradley R, Wiseman J. Yields of Farmed Species. Cambridge: Nottingham University Press. pp. 435-462.

Gerland P, Raftery AE, Ševčíková H, Li N, Gu D, Spoorenberg T, Alkema L, Fosdick BK, Chunn J, Lalic N, Bay G, Buettner T, Heilig GK, Wilmoth J. 2014. World population stabilization unlikely this century. Science, 346:234-237.

Gibbs EPJ. 2014. The evolution of one health: a decade of progress and challenges for the future. Vet Rec, 174:85-91.

González-Recio O, Miguel AT, Bach A. 2015. Past, present, and future of epigenetics applied to livestock breeding. Front Genet, 6:305-313

Haley CS, Lee GJ, W bb R, Knott SA. 1993. Evidence on the genetic control of LH release in response to $\mathrm{GnRH}$ from crosses between selected lines of sheep. Livest Prod Sci, 37:153-167.

Hedenus F, Wirsenius S, Johansson DJA. 2014. The importance of reduced meat and dairy consumption for meeting stringent climate change targets. Climatic Change 124:79-91.

Herrero M, Henderson B, Havlík P, Thornton PK, Conant $R T$, Smith $P$, W isenius $S$, Hristov $A N$, Gerber P, Gill M, Butterbach-Bahl K, Valin $\mathbf{H}$, Garnett T, Stehfest E. 2016. Greenhouse gas mitigation potentials in the livestock sector. Nat Climate Change, 6:452-461.

Hickey JM, Whitelaw BC, Gorjanc G. 2016. Promotion of alleles by genome editing in livestock breeding programmes. J Anim Breed Genet, 133:83-84.

Hill WG. 2016. Is continued genetic improvement of livestock sustainable? Genetics, 202:877-881.

Homer EM, Y. Gao Y, Meng X, Dodson A, Webb R, Garnsworthy PC. 2013. Technical note: a novel approach to the detection of estrus in dairy cows using ultra-wideband technology. J Dairy Sci, 96:6529-6534.

Intergovernmental Panel on Climate Change. 2012. Managing the risks of extreme events and disasters to 
advance climate change adaptation. A Special Report of the Intergovernmental Panel on Climate Change. Edited by CB Field, V Barros, TF Stocker, D Qin, DJ Dokken, KL Ebi, MD Mastrandrea, KJ Mach, G-K Plattenr, SK Allen, M Tignor, PM Midgley. Cambridge, UK; Cambridge University Press. $582 \mathrm{pp}$.

Intergovernmental Panel on Climate Change. 2013. Climate Change 2013: The Physical Science Basis. Contribution of Working Group I to the Fifth Assessment Report of the Intergovern- mental Panel on Climate Change. Edited by TF Stocker, D Qin, G-K Plattner, M Tignor, SK Allen, J Boschung, A Nauels, Y Xia, V Bex, PM Midgley. Cambridge, UK: Cambridge University Press. pp 1-1535.

Ireland JJ, Smith GW, Scheetz D, Jimenez-Krassel F, Folger JK, Ireland JL, Mossa F, Lonergan $\mathbf{P}$, Evans AC. 2011. Does size matter in females? An overview of the impact of the high variation in the ovarian reserve on ovarian function and fertility, utility of anti- Mullerian hormone as a diagnostic marker for fertility and causes of variation in the ovarian reserve in cattle. Reprod Fertil Dev, 23:1-14.

Kearney J. 2010. Food consumption trends and drivers. Philos Trans R Soc Lond B Biol Sci, 365:2793-2807.

Lamb GC, Dahlen CR, Larson JE, Marquezini G, Stevenson JS. 2010. Control of the estrous cycle to improve fertility for fixed-time artificial insemination in beef cattle: a review. J Anim Sci, 88:E181-E192.

Mapletoft RJ, Bó GA. 2011. The evolution of improved and simplified superovulation protocols in cattle. Reprod Fertil Dev, 24:278-283.

Meuwissen T, Ben Hayes B, Goddard M. 2016 Genomic selection: a paradigm shift in animal breeding. Anim Frontiers, 6:6-14.

Morotti F, Barreiros TRR, Machado FZ, S.M. González SM, Marinho LSR, Seneda MM. 2015. Is the number of antral follicles an interesting selection criterium for fertility in cattle? Anim Reprod, 12:479-486. Murphy BD. 2012. Research in animal reproduction: Quo vadimus? Anim Reprod, 9:217-222.

Randolph TF, Schelling E, Grace D, Nicholson CF, Leroy JL, Cole DC, Demment MW, Omore A, Zinsstag J, Ruel M. 2007. Invited review: role of livestock in human nutrition and health for poverty reduction in developing countries. J Anim Sci, 85:27882800

Ranganathan J, Vennard D, Waite R, Dumas P, Lipinski B, Searchinger T. 2016. GLOBAGRI-WRR Model Authors. Shifting diets for a sustainable future. Installment 11 of "Creating a Sustainable Future". World Resources Institute. 90 pp. Available from: http://www.wri.org/publication/shifting-diets.

Rupp R, Mucha S, Larroque H, McEwan J, Conington J. 2016. Genomic application in sheep and goat breeding. Anim Frontiers, 6:39-44.

Sartori R, Gimenes LU, Monteiro Jr PLJ, Melo LF, Baruselli PS, Bastos MR. 2016a. Metabolic and endocrine differences between Bos taurus and Bos indicus females that impact the interaction of nutrition with reproduction. Theriogenology, 86:32-40.

Sartori R, Prata AB, Monteiro Jr PLJ, Viana JHM, Vilela ER, Pereira MH, Vasconcelos JLM, Pontes G,
Sanches BV, Figueiredo ACS, Baruselli PS. 2016b. Update and overview on assisted reproductive technologies (ARTs) in Brazil. Anim Reprod, 13:300312.

Sinclair KD, Webb R. 2005. Reproductive rate in farm animals: strategies to overcome biological constraints through the use of advanced reproductive technologies. In: Sylvester-Bradley R, Wiseman J. Yields of farmed species. Cambridge, UK: Nottingham University Press. pp. 51-88.

Sinclair KD, Allegrucci C, Singh R, Gardner DS, Sebastian S, Bispham J, Thurston A, Huntley JF, Rees WD, Maloney CA, Lea RG, Craigon J, McEvoy TG, Young LE. 2007. DNA methylation, insulin resistance, and blood pressure in offspring determined by maternal periconceptional B vitamin and methionine status. Proc Nat Acad Sci, 104:19351-19356.

Smith P, Bustamante M, Ahammad H, Clark H, Dong H, Elsiddig EA, Haberl H, Harper R, House J, Jafari M, Masera O, Mbow C, Ravindranath NH, Rice CW, Robledo Abad C, Romanovskaya A, Sperling F, Tubiello F. 2014. Agriculture, Forestry and Other Land Use (AFOLU). In: Edenhofer O, PichsMadruga R, Sokona Y, Farahani E, Kadner S, Seyboth $\mathrm{K}$, Adler A, Baum I, Brunner S, Eickemeier $\mathrm{P}$, Kriemann B, Savolainen J, Schlömer S, von Stechow C, Zwickel T Minx JC. (Ed.). Climate Change 2014: Mitigation of Climate Change. Contribution of Working Group III to the Fifth Assessment Report of the Intergovernmental Panel on Climate Change. Cambridge, UK: Cambridge University Press. Available on: https://www.ipcc.ch/pdf/assessmentreport/ar5/wg3/ipcc_wg3_ar5_chapter11.pdf.

Springmann M, Mason-D'Croz D, Robinson S, Garnett T, Godfray HCJ, Gollin D, Rayner M, Ballon P, Scarborough P. 2016. Global and regional health effects of future food production under climate change: a modelling study. Lancet, 387:1937-1946.

Sylvester-Bradley R, Wiseman J. 2005. Yields of Farmed Species. Cambridge, UK: Nottingham University Press. 1-651 pp.

United Nations Framework Convention on Climate Change. Conference of the Parties 21st Session, Paris 30 November to 11 December 2015. Adoption of the Paris Agreement. Available on: http://unfecc.int /resource/docs/2015/cop21/ eng/109r01.pdf.

Schader C, Muller A, El-Hage Scialabba N, Hecht J, Isensee A, Erb K-H, Smith P, Makkar HPS, Klocke P, Leiber F, Schwegler P, Stolze M, Niggli U. 2016. Impacts of feeding less food-competing feedstuffs to livestock on global food system sustainability $J R S O c$ Interface, 12:20150891. http://dx.doi.org/10.1098/ rsif.2015.0891.

UK strategy for agricultural technologies. 2013. 52 pp. Available on: www.gov.uk/government/uploads/ system/uploads/attachment_data/file/227259/9643-BISUK Agri Tech Strategy Accessible.pdf.

UK Government. 2013. A UK Strategy for Agricultural Technologies. $56 \mathrm{pp}$. Available on: https://www.gov.uk/government/publications/uk-

agricultural-technologies-strategy.

Webb R, Stubbings L, Gregson K, Robinson JJ. 
2005. Yields of sheep: physiological and technological limitations. Pages 463-494. In: Sylvester-Bradley R, Wiseman J. Yields of Farmed Species. Cambridge, UK: Nottingham University Press.

Wegener HC. 2012. A15: Antibiotic resistance linking human and animal health. National Academy Press. Available on: http://www.ncbi.nlm.nih.gov/ books/NBK114485.

Wheeler T, von Braun J. 2013. Climate change impacts on global food security. Science, 341:508-513.

Wilkinson JM. 2011. Re-defining efficiency of feed use by livestock. Animal, 5:1014-1022.

World Health Organisation. 2012. Micronutrient deficiencies. Available on: www.who.int/nutrition/ topics/ida/en.
World Health Organisation. 2015. Obesity and overweight. Fact sheet Number 311. Available on: www.who.int/mediacentre/factsheets/fs311/en.

World Hunger and Poverty Facts and Food Statistics. 2015. Available on: www.worldhunger.org/ 2015-world-hunger-and-poverty-facts-and-statistics/\# micronutrients 1 .

Zalasiewicz J, Waters CN, Williams M, Barnosky AD, Cearreta A, Crutzen P, Ellis E, Ellis MA, Fairchild IJ, Grinevald J, Leinfelder R, McNeill J, Poirier C, Richter D, Steffen W, Vidas D, Wagreich M, Wolfe AP, Zhisheng A. 2015. When did the Anthropocene begin? A mid-twentieth century boundary level is stratigraphically optimal. Quat Int, 383:204-207. 